\title{
A Preliminary Analysis of CRM Practices among Banks from the Customers’ Perspectives
}

\author{
Izah Mohd Tahir (Corresponding Author) \\ Faculty of Business Management \& Accountancy \\ University Sultan Zainal Abidin (UniSZA) \\ 21300 Kuala Terengganu \\ Terengganu, Malaysia \\ Email: izah@unisza.edu.my \\ Zuliana Zulkifli \\ Faculty of Business Management \& Accountancy \\ University Sultan Zainal Abidin (UniSZA) \\ 21300 Kuala Terengganu \\ Terengganu, Malaysia \\ Email: azym_blue02@yahoo.com
}

Received: July 09, 2011 Accepted: July 14, 2011 DOI: 10.5296/jpag.v1i1.783

\begin{abstract}
Firms especially banks have realized the importance of becoming customer oriented and therefore Customer Relationship Management Practices (CRM) is seen to be very important to these firms. This study reports on the preliminary findings of CRM practices among banks from the customers' perspectives. Five dimensions comprising of 48 statements are proposed for this study: Customer Acquisition (11 items), Customer Response (10 items), Customer Knowledge (10 items), Customer Information System (9 items), and Customer Value Evaluation (8 items). The results of the internal consistency tests are considered good with Cronbach's alphas ranging from 0.73 to 0.92 . Overall, the results suggest that respondents somewhat agreed and strongly agreed on all the items proposed. The results from this preliminary study are important to us to understand the perceptions of the customers so as to adjust and modify items that are important and not.
\end{abstract}

Keywords: Customer Relationship Management, banks, customers’ perspectives 


\section{Introduction}

In its simple term, Customer relationship management (CRM) manages the relationships between a firm and its customers. Managing customer relationships requires managing customer knowledge. Thus CRM and knowledge management are directed towards improving and continuously delivering good services to customers. CRM begins with the concept of relationship marketing introduced by Berry in 1983 (as cited by Ryals and Payne, 2001). This concept is examined to attract and maintain the multi service organizations to enhance customer relationships with organizations. Increasing the relationship with the high demand from customer changed the term from relationship marketing to the customer relationship management (CRM). It involves organizations providing and satisfying customers' needs. This will in turn, maintaining customer loyalty and ultimately contribute to the profitability of the firms. However, previous researchers had determined customer relationship management (CRM) in different ways. For example, Ryals and Payne (2001) defined CRM as a management approach by using IT to build a long-term relationship with customers and profitability for organizations.

Chen and Ching (2004) described CRM as a relationship of information technology (IT) that described customers from database to be more effective in relationship with customers. Mylonakis (2009) recognized CRM as the most innovative process to create loyalty by maintaining a long term relationships of trust between customers and organization. Brown (2000, pp. 8) defined customer relationship management (CRM) as "a process of acquiring, retaining and growing profitable customers and business strategy that aims to understand, anticipate, and manage the needs of an organization's current and potential customers”. Therefore, CRM is a comprehensive strategy and process which focuses to establish, maintain, and enhance relationship with customer to create value for the organizations (Jham and Kalem, 2008).

Nowadays, CRM is an important issue to increase opportunities in using data which will be used to understand customers and implement well in relationship marketing strategies. CRM is also important because it is more advanced in financial service that represents the largest sector of UK gross domestic product (GDP) (Ryals and Payne, 2001). CRM is able to create sustainable competitive advantage by being understanding, communicating, delivering and developing existing customers and acquiring new customers for organization (Zineldin, 2005). To understand more in customer relationship management, we first need to understand three components which are customer, relationship and their management (Peppers and Rogers, 2004). Relationship is not just making customers satisfied with the products or services by lowering the price but it is more on how managers treat them and how they feel when dealing with the organizations.

More often, managers always make mistakes by seeing customers' satisfaction from their eye not from customers' eye (Peppers and Rogers, 2004). Banking sector is a customer-oriented service where the customer is the focus. Research is needed in such sector to understand customers' need and attitude so as to build a long relationship with them. Many researchers who study on customer relationship CRM focus on organizations' perspectives to retain 
customers in their organizations. Dutta and Dutta (2009), studied on customer expectations and perceptions; Jham and Kaleem (2008) on customer satisfaction; Park and Kim (2003) on a framework of dynamic CRM. Research on CRM for financial services sector is still lacking (Lu and Shang, 2007). Therefore, this study will contribute to the existing literature and we anticipate that that by examining the perceptions of customers on CRM practices among banks could contribute to the successful implementation of CRM programmes.

The objective of the study is to report on the pilot study on CRM practices among banks from the customers' perspectives. The paper is organized as follows; Section Two will highlight the literatures pertinent to the study followed by methodology in Section 3. Section 4 discusses the results and finally Section 5 concludes.

\section{Literature Review}

The following literature review section provides a discussion and argument for the selection of the variables for the empirical investigation on CRM. The research variables were adopted from previous literature. Almossawi (2001) examined the bank selection criteria being employed by college students in Bahrain. This author focused on younger segment as one of marketing strategies to attract new customers and to understand the potential customers in selecting the banks. There are three reasons why the author chose younger segment: as a sizeable market segment; tend to be a good savers; and they will open bank accounts after completing their study and start working in companies. The results show that there are four selection criteria of banks in Bahrain namely technology, convenience, financial benefits and employees or customer interactions. From the four factors identified, the first factor called technology or reputation of bank is important criteria for selection of the bank followed by convenience or accessibility which includes ATM locations, branch locations and parking space nearby. The third important factor is financial benefits which include the charges, fees and loans. The least important factor is employee or customer interactions for example the friendliness of bank personnel and reception at the bank.

Gordon (2002) discussed about how company wants to improve their performance of CRM and the changing role of senior manager in developing a relationship-oriented organization. A definition from best practices companies shows that "CRM is a series of strategies and processes that create new and mutual value for individual customers, builds preference for their organizations and improves business results over lifetime of association with their customers". The best companies will create the vision on how CRM will change their companies which focus on delivering the value. Today, the most important for companies to focus is on strategic capabilities rather than specific strategy. The author found that the best companies did not adopt the CRM technology first but develop a balance approach to implement CRM strategic capabilities. There are four main CRM strategic capabilities: technology that support CRM; people who manage CRM that has the skills, abilities and attitudes; process that companies use to access and interact with their customers in the pursuit of new value and mutual satisfaction; and knowledge and insight use to add value to customer data so that they acquire the knowledge and insight needed to deepen the relationships that matter (Gordon, 2002). In summary, there are four CRM strategic 
capabilities: process; people; technology; and knowledge (Parvatiyar and Sheth, 2001).

Wang et.al. (2004) developed an integrative framework for customer value and CRM performance based on the identification of the key dimensions of customer value namely functional value, social value, emotional value and perceived sacrifices. The results found that, customer satisfaction, brand loyalty, functional values have positive effect on customer behaviour based on CRM performance where brand loyalty is the most significant influence on customer behaviour.

Sin et. al. (2005) identified four dimensions of CRM in their study namely key customer focus, CRM organization, technology-based CRM and knowledge management. These dimensions were based on the definition of CRM where CRM involve the strategy, technology and process to identify, attract and increase retention of profitable customers by managing relationships with them for long term relationships (Parvatiyar and Sheth, 2001). Furthermore, the researchers developed the reliable and measurement scale for these dimensions of CRM because limited research had done this before. The finding showed that the CRM scale had a high degree of reliability and validity. CRM is a critical success factor for business performance indirectly and also for financial performance where it increases the organization's profit. The customer perceptions directly influence customer satisfaction of services provided by the banks. The customer satisfaction will create customer loyalty and will increase organization's profit (Matzler, et. al., 2006). The authors explored the dimension of price satisfaction by using a sample of 160 part time students at an Austrian university. There were five dimensions of price satisfaction employed: price fairness; reliability of prices; transparency of prices; relative price; and price quality ratio. They found that the price quality ratio and price fairness were important to customers than relative ratio. The result also indicated that banks should deliver right quality at the right price than focus on price offered by their competitors.

The topic of CRM has attracted a lot of attention among academicians and practitioners but as far as we are aware, the study on this topic is still lacking especially in the Malaysian context. Many researches have been done in various industries especially in the banking sector that focussing on customer-oriented services (Ndubisi et. al., 2007; Rootman et. al., 2008; and Dutta and Dutta, 2009). Lu and Shang (2007) explored the CRM perceptions in freight forwarder services from managerial perspectives. They had come out with six dimensions of CRM namely customer acquisition, customer response, customer knowledge, customer information system, customer value evaluation, and customer information process. Their study found that customer response dimension was the most important dimension compared to others as this dimension are related to the communication with customers, customer's problems and complaints, and the way services are provided to the customers. This study also provides a new framework for identifying the CRM dimensions based on firm's service attributes.

Today, there is variety of banking products like automated teller machine, phone banking, tele-banking, and internet banking, and so on. Relationship Marketing (RM) has the ability to build loyal customers through understanding customers' needs and this can reduce the cost. 
There is less empirical evidence in Malaysia about the actual direct and indirect influences of the underpinnings of RM on customer loyalty. Ndubisi et. al., (2007) examined the impact of the relationship marketing called commitment, competence, communication and conflict handling as an independent variables and customer loyalty as dependent variable with the mediating variables i.e. trust and relationship quality Results of their study showed that the relationship dimensions were predicted in trust and relationship quality. In addition, trust and relationship quality had significantly influence customer loyalty.

Rootman et. al. (2008) investigated the variables that influence the effectiveness of CRM strategies in banks. These variables were attitude, knowledgeability and two-way communication related to bank employees. Attitude refers to the reaction, response, or behaviour displayed by bank employees towards their jobs. The employee's knowledgeability means the ability to remember or to implement banking procedures policies, products and services and two-way communications means the communication from bank management to customers and vice versa. Results from in this study indicated that attitude and knowledgeability had influenced the effectiveness of CRM strategies in banks at the 99 percent significant level. This result showed that the relationship between customers and banks are influenced by bank employee's attitude such as the way they communicate with their customers especially for the bank employees at the front enquiry desk and customer service. The relationship between customers and banks influenced bank employee's knowledge about the products and services. Thus, bank's employees need to understand the bank's mission and the information of their products and services especially for new employees. Reward for the best employees should be given as a motivation to increase their attitude and knowledge.

Based on the work of others and the review of selected literatures, we propose a framework as in Figure 1.

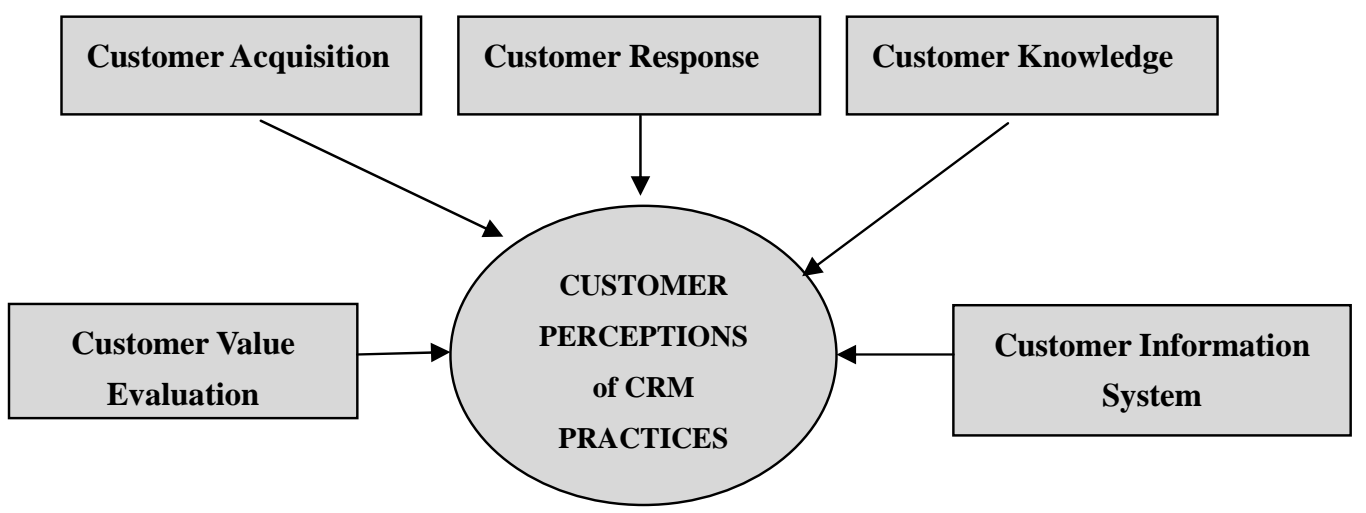

Figure 1: Theoretical Framework

\section{Methodology}

\subsection{Research Design and Instrument}

For this study we will use primary data by means of questionnaire for collection of data. Questionnaires are based on the work of Lu and Shang (2007) with modifications to suit this 
particular study. Questionnaires for this pilot study were distributed personally to selected respondents and it took 30 minutes to answer. The sampling technique for this pilot study is purposive sampling.

Details of the measurement are as follows:

1. For demographics gender, age, education level, employment, online banking usage, number of visits in a month and banks that are most preferable, the respondents were asked to tick the respective boxes.

2. For Customer Acquisition, Customer Response, Customer Knowledge, Customer Information System and Customer Value Evaluation, the respondents were asked to rank from strongly disagree to 5 strongly agree based on 5 point Likert scale.

\section{Data Analysis and Results}

\subsection{Profile of the Respondents}

For this pilot study we asked 20 respondents to answer the questionnaires. Only 13 were usable for analysis. Female respondents dominated the sample which is 77 percent. Majority are in the age between 20 to 35 years old and with undergraduate degree qualification. More than half (54 percent) do not use online banking and majority of the respondents (46 percent) visit their banks more than five times. Finally, bank that is most preferable is Bank Islam Malaysia Berhad.

\subsection{Internal Consistency Test}

Cronbach's Alpha is used to measure the internal consistency of the items used in the study. Table 1 shows that the values of the Cronbach's alpha ranges from 0.73 to 0.92 . This indicates a good internal consistency of the items in the scale.

Table 1: Reliability Analysis: Cronbach’s Alpha Value

\begin{tabular}{|l|c|c|}
\hline \multicolumn{1}{|c|}{ Dimensions } & Items & Cronbach's Alpha \\
\hline Customer Acquisition & 11 & 0.84 \\
\hline Customer Response & 10 & 0.73 \\
\hline Customer Knowledge & 10 & 0.77 \\
\hline Customer Information System & 9 & 0.76 \\
\hline Customer Value Evaluation & 8 & 0.88 \\
\hline \multicolumn{1}{|c|}{ Overall score } & 48 & 0.92 \\
\hline
\end{tabular}

\subsection{Levels of Agreement of CRM Practices}

The analysis of the data in this section will be done separately for each dimension. The responses under rating 1 (strongly disagree) and 2 (disagree) have been combined to indicate disagreement with a statement. Consequently, ratings 4 (agree) and 5 (strongly agree) have 
been combined to indicate agreement with a statement.

\subsubsection{Customer Acquisition}

The results for statement under customer acquisition are presented in Table 2. The results show that the statements with the highest percentage of respondents who stated that they strongly agreed or agreed with statements no. 10 and no. 11 (77 percent). This is followed by statements no. 8 (69 percent), no. 7 (62 percent), and no. 1 and no. 2 (54 percent). From the table, we can also see that the highest percentage of respondents said they were undecided about were statements no. 3, no. 5 and no. 6: "My bank uses customer information to attract new customers", My bank provides a variety of service items and information”, and "My bank provides services to meet my specific requirements”, all with 62 percent; and statement no. 4: "My bank uses customer information to plan new products and services" (54 percent). This findings show that customers are not sure whether banks use their information to do the planning on the products and services.

Table 2: Level of Agreement of CRM Practices- Customer Acquisition

\begin{tabular}{|c|c|c|c|c|c|c|c|c|c|c|c|}
\hline No & Statements & \multicolumn{2}{|c|}{ SD } & \multicolumn{2}{|c|}{ Disagree } & \multicolumn{2}{|c|}{ Neutral } & \multicolumn{2}{|c|}{ Agree } & \multicolumn{2}{|c|}{ SA } \\
\hline & & $\mathrm{n}$ & $\%$ & $\mathrm{n}$ & $\%$ & $\mathrm{n}$ & $\%$ & $\mathrm{n}$ & $\%$ & $\mathrm{n}$ & $\%$ \\
\hline 1 & $\begin{array}{l}\text { My bank uses different measures to meet } \\
\text { customers' urgent requirements. }\end{array}$ & 0 & 0 & 2 & 15 & 4 & 31 & 6 & 46 & 1 & 8 \\
\hline 2 & $\begin{array}{l}\text { My bank uses different approaches to attract } \\
\text { target customers. }\end{array}$ & 0 & 0 & 1 & 8 & 5 & 38 & 7 & 54 & 0 & 0 \\
\hline 3 & $\begin{array}{l}\text { My bank uses customer information to } \\
\text { attract new customers. }\end{array}$ & 2 & 15 & 3 & 23 & 8 & 62 & 0 & 0 & 0 & 0 \\
\hline 4 & $\begin{array}{l}\text { My bank uses customer information to plan } \\
\text { new products and services. }\end{array}$ & 0 & 0 & 1 & 8 & 7 & 54 & 4 & 30 & 1 & 8 \\
\hline 5 & $\begin{array}{l}\text { My bank provides a variety of service items } \\
\text { and information. }\end{array}$ & 0 & 0 & 0 & 0 & 8 & 62 & 1 & 8 & 4 & 30 \\
\hline 6 & $\begin{array}{l}\text { My bank provides services to meet my } \\
\text { specific requirements. }\end{array}$ & 0 & 0 & 0 & 0 & 8 & 62 & 4 & 30 & 1 & 8 \\
\hline 7 & My bank fulfils its promises on time. & 0 & 0 & 1 & 8 & 4 & 30 & 7 & 54 & 1 & 8 \\
\hline 8 & $\begin{array}{l}\text { My bank is able to tailor its products and } \\
\text { services to meet my needs. }\end{array}$ & 0 & 0 & 0 & 0 & 4 & 31 & 9 & 69 & 0 & 0 \\
\hline 9 & $\begin{array}{l}\text { My bank actively seeks to provide me a } \\
\text { total financial solution. }\end{array}$ & 0 & 0 & 1 & 8 & 6 & 46 & 6 & 46 & 0 & 0 \\
\hline 10 & $\begin{array}{l}\text { My bank staffs are knowledgeable and } \\
\text { possess necessary information on requested } \\
\text { services. }\end{array}$ & 0 & 0 & 0 & 0 & 3 & 23 & 8 & 62 & 2 & 15 \\
\hline 11 & $\begin{array}{l}\text { My bank staffs show sincere interest in } \\
\text { solving my problems. }\end{array}$ & 0 & 0 & 0 & 0 & 3 & 23 & 8 & 62 & 2 & 15 \\
\hline
\end{tabular}




\subsubsection{Customer Response}

Table 3 presents the results relating to dimension 2 - customer response. The results show that only 3 statements that respondents agreed or strongly agreed upon; these are statements no. 4: "My bank offers me with convenient services" (61 percent), no. 6: "My bank offers me with useful online products and services" (61 percent) and no. 8: "My bank provides me with enough information to allow me to be well-informed when making choices" (54 percent). The respondents are not sure with the statements nos. 1, 2, 3, 5, 7, 9 and 10.

\subsubsection{Customer Knowledge}

Respondents either agreed or strongly agreed in 7 statements out of 10 statements in this dimension, whereas 3 statements that they are unsure of. The statements that they are unsure of are related to statement no. 5: "My bank often encourages me to introduce other customers to purchase their products and services" (62 percent); no. 6: "My bank often insists me in using bank's services and products" (54 percent); and no. 7: "My bank has clear objectives and strategies to meet my needs and the performance of my relationships” (61 percent). See Table 4.

Table 3: Level of Agreement of CRM Practices- Customer Response

\begin{tabular}{|c|c|c|c|c|c|c|c|c|c|c|c|}
\hline No & Statements & \multicolumn{2}{|c|}{ SD } & \multicolumn{2}{|c|}{ Disagree } & \multicolumn{2}{|c|}{ Neutral } & \multicolumn{2}{|c|}{ Agree } & \multicolumn{2}{|c|}{ SA } \\
\hline & & $\mathrm{n}$ & $\%$ & $\mathrm{n}$ & $\%$ & $\mathrm{n}$ & $\%$ & $\mathrm{n}$ & $\%$ & $\mathrm{n}$ & $\%$ \\
\hline 1 & $\begin{array}{l}\text { My bank uses phone calls, e-mails, and } \\
\text { personnel visits to communicate with me. }\end{array}$ & 1 & 8 & 3 & 23 & 6 & 46 & 2 & 15 & 1 & 8 \\
\hline 2 & $\begin{array}{l}\text { My bank rapidly responds to my problems, } \\
\text { suggestions, and complaints. }\end{array}$ & 0 & 0 & 0 & 0 & 7 & 54 & 6 & 46 & 0 & 0 \\
\hline 3 & $\begin{array}{l}\text { My bank would initiatively understand my } \\
\text { service requirements and expectations. }\end{array}$ & 0 & 0 & 0 & 0 & 9 & 69 & 4 & 31 & 0 & 0 \\
\hline 4 & $\begin{array}{l}\text { My bank offers me with convenient } \\
\text { services. }\end{array}$ & 0 & 0 & 0 & 0 & 5 & 39 & 6 & 46 & 2 & 15 \\
\hline 5 & $\begin{array}{l}\text { My bank offers a range of credit facilities } \\
\text { to meet my requirements. }\end{array}$ & 0 & 0 & 1 & 8 & 6 & 46 & 5 & 38 & 1 & 8 \\
\hline 6 & $\begin{array}{l}\text { My bank offers me with useful online } \\
\text { products and services. }\end{array}$ & 0 & 0 & 0 & 0 & 5 & 39 & 6 & 46 & 2 & 15 \\
\hline 7 & $\begin{array}{l}\text { My bank offers me with products that } \\
\text { reflect my earnings and wealth. }\end{array}$ & 1 & 8 & 0 & 0 & 10 & 76 & 1 & 8 & 1 & 8 \\
\hline 8 & $\begin{array}{l}\text { My bank provides me with enough } \\
\text { information to allow me to be } \\
\text { well-informed when making choices. }\end{array}$ & 0 & 0 & 0 & 0 & 6 & 46 & 6 & 46 & 1 & 8 \\
\hline 9 & $\begin{array}{l}\text { My bank staffs are sufficiently empowered } \\
\text { to solve difficult banking problems. }\end{array}$ & 0 & 0 & 1 & 8 & 8 & 61 & 4 & 31 & 0 & 0 \\
\hline 10 & $\begin{array}{l}\text { My bank takes actions for my erroneous } \\
\text { transaction. }\end{array}$ & 0 & 0 & 0 & 0 & 7 & 54 & 6 & 46 & 0 & 0 \\
\hline
\end{tabular}


Table 4: Level of Agreement of CRM Practices- Customer Knowledge

\begin{tabular}{|c|l|c|c|c|c|c|c|c|c|c|c|}
\hline No & \multicolumn{1}{|c|}{ Statements } & \multicolumn{2}{|c|}{ SD } & \multicolumn{1}{|c|}{ Disagree } & \multicolumn{2}{|c|}{ Neutral } & \multicolumn{2}{|c|}{ Agree } & \multicolumn{2}{|c|}{ SA } \\
\hline 1 & \multicolumn{1}{|c|}{$\begin{array}{l}\text { My bank's operating hours are convenient to } \\
\text { me. }\end{array}$} & 0 & 0 & 1 & 8 & 3 & 23 & 9 & 69 & 0 & 0 \\
\hline 2 & $\begin{array}{l}\text { My bank offers me with comprehensive } \\
\text { range of investment products. }\end{array}$ & 0 & 0 & 0 & 0 & 4 & 31 & 5 & 61 & 1 & 8 \\
\hline 3 & $\begin{array}{l}\text { My bank offers me with innovative loan } \\
\text { services. }\end{array}$ & 0 & 0 & 1 & 7 & 5 & 39 & 5 & 39 & 2 & 15 \\
\hline 4 & $\begin{array}{l}\text { My bank understands my individual needs } \\
\text { and circumstances. }\end{array}$ & 0 & 0 & 3 & 23 & 2 & 15 & 8 & 62 & 0 & 0 \\
\hline 5 & $\begin{array}{l}\text { My bank often encourages me to introduce } \\
\text { other customers to purchase their products } \\
\text { and services. }\end{array}$ & 1 & 8 & 2 & 15 & 8 & 62 & 2 & 15 & 0 & 0 \\
\hline 6 & $\begin{array}{l}\text { My bank often insists me in using bank's } \\
\text { services and products. }\end{array}$ & 1 & 8 & 1 & 8 & 7 & 54 & 4 & 30 & 0 & 0 \\
\hline 7 & $\begin{array}{l}\text { My bank has clear objectives and strategies } \\
\text { to meet my needs and the performance of my } \\
\text { relationships. }\end{array}$ & 0 & 0 & 0 & 0 & 8 & 61 & 5 & 39 & 0 & 0 \\
\hline 8 & $\begin{array}{l}\text { My bank does not misuse its customer's } \\
\text { knowledge. }\end{array}$ & 0 & 0 & 1 & 8 & 4 & 31 & 6 & 46 & 2 & 15 \\
\hline 9 & $\begin{array}{l}\text { The terms and conditions of my bank are } \\
\text { better than others. }\end{array}$ & 0 & 0 & 0 & 0 & 6 & 46 & 6 & 46 & 1 & 8 \\
\hline 10 & My bank always meets my expectations. & 0 & 0 & 1 & 8 & 5 & 38 & 6 & 46 & 1 & 8 \\
\hline
\end{tabular}

\subsubsection{Customer Information System}

The results in Table 5 show that the highest percentage of respondents who stated that they strongly agreed or agreed with a statement did so in relation to statement no. 9: "Electronic bank provides me with a security system to protect my transaction" (85 percent). The second most favourable response is related to statement no. 3: "My bank provides tele-banking and internet banking facilities” (77 percent), followed by that in respect to statement no. 4: “ATM machines are available at most places (70 percent), statement no. 2: "My bank has modern equipments and technologies”, (69 percent) and statement no. 1: 'My bank's system allows me to perform my banking needs”, (69 percent). On the other hand, the statements which the highest percentage of respondents said they were undecided about were statement no. 5: "My bank has a computer system for recording my purchases and services” (46 percent); no. 6: "My bank uses new technologies to improve communication with me"; statement no. 7: "My bank has a system to make it easier for me to do business with the bank" and statement no. 8: "My bank uses technology to automate marketing, sales and service functions", (46 percent). 
Table 5: Level of Agreement of CRM Practices- Customer Information System

\begin{tabular}{|c|c|c|c|c|c|c|c|c|c|c|c|}
\hline \multirow[t]{2}{*}{ No } & \multirow[t]{2}{*}{ Statements } & \multicolumn{2}{|c|}{ SD } & \multicolumn{2}{|c|}{ Disagree } & \multicolumn{2}{|c|}{ Neutral } & \multicolumn{2}{|c|}{ Agree } & \multicolumn{2}{|c|}{ SA } \\
\hline & & $\mathrm{n}$ & $\%$ & $\mathrm{n}$ & $\%$ & $\mathrm{n}$ & $\%$ & $\mathrm{n}$ & $\%$ & $\mathrm{n}$ & $\%$ \\
\hline 1 & $\begin{array}{l}\text { My bank’s system allows me to perform my } \\
\text { banking needs. }\end{array}$ & 0 & 0 & 0 & 0 & 4 & 31 & 8 & 61 & 1 & 8 \\
\hline 2 & $\begin{array}{l}\text { My bank has modern equipments and } \\
\text { technologies. }\end{array}$ & 0 & 0 & 0 & 0 & 4 & 31 & 5 & 38 & 4 & 31 \\
\hline 3 & $\begin{array}{l}\text { My bank provides tele-banking and internet } \\
\text { banking facilities. }\end{array}$ & 0 & 0 & 0 & 0 & 3 & 23 & 8 & 62 & 2 & 15 \\
\hline 4 & ATM machines are available at most places. & 0 & 0 & 2 & 15 & 2 & 15 & 7 & 54 & 2 & 16 \\
\hline 5 & $\begin{array}{l}\text { My bank has a computer system for } \\
\text { recording my purchases and services. }\end{array}$ & 0 & 0 & 1 & 8 & 6 & 46 & 5 & 39 & 1 & 7 \\
\hline 6 & $\begin{array}{l}\text { My bank uses new technologies to improve } \\
\text { communication with me. }\end{array}$ & 0 & 0 & 0 & 0 & 9 & 69 & 3 & 23 & 1 & 8 \\
\hline 7 & $\begin{array}{l}\text { My bank has a system to make it easier for } \\
\text { me to do business with the bank. }\end{array}$ & 0 & 0 & 0 & 0 & 7 & 54 & 6 & 46 & 0 & 0 \\
\hline 8 & $\begin{array}{l}\text { My bank uses technology to automate } \\
\text { marketing, sales and service functions. }\end{array}$ & 0 & 0 & 0 & 0 & 7 & 54 & 6 & 46 & 0 & 0 \\
\hline 9 & $\begin{array}{l}\text { Electronic bank provides me with a security } \\
\text { system to protect my transaction. }\end{array}$ & 0 & 0 & 0 & 0 & 2 & 15 & 10 & 77 & 1 & 8 \\
\hline
\end{tabular}

\subsubsection{Customer Value Evaluation}

The results in Table 6 show that the respondents tend to agree or strongly agree on all the statements with the highest percentages are statements no. 8: "I am confident with the security level of my bank" (85 percent); statement no. 5: "The services at my bank make me want to use banking services" (85 percent); and statement no. 4: "I enjoy my bank services" (85 percent).

Table 6: Level of Agreement of CRM Practices -Customer Value Evaluation

\begin{tabular}{|c|l|c|c|c|c|c|c|c|c|c|c|c|}
\hline No & \multicolumn{1}{|c|}{ Statements } & \multicolumn{2}{|c|}{ SD } & \multicolumn{2}{c|}{ Disagree } & \multicolumn{2}{c|}{ Neutral } & \multicolumn{3}{|c|}{ Agree } & \multicolumn{2}{c|}{ SA } \\
\hline & \multicolumn{1}{|c|}{$\mathrm{n}$} & $\%$ & $\mathrm{n}$ & $\%$ & $\mathrm{n}$ & $\%$ & $\mathrm{n}$ & $\%$ & $\mathrm{n}$ & $\%$ \\
\hline 1 & My bank always delivers superior services. & 0 & 0 & 0 & 0 & 4 & 31 & 9 & 69 & 0 & 0 \\
\hline 2 & My bank offers me high quality services. & 0 & 0 & 0 & 0 & 3 & 23 & 8 & 62 & 2 & 15 \\
\hline 3 & I can put my trust on any services provided & 0 & 0 & 0 & 0 & 4 & 31 & 7 & 54 & 2 & 15 \\
\hline 4 & I enjoy my bank services. & 0 & 0 & 0 & 0 & 2 & 15 & 9 & 70 & 2 & 15 \\
\hline 5 & $\begin{array}{l}\text { The services at my bank make me want to use } \\
\text { banking services. }\end{array}$ & 0 & 0 & 0 & 0 & 2 & 15 & 9 & 70 & 2 & 15 \\
\hline 6 & I feel relaxed using my bank services. & 0 & 0 & 0 & 0 & 4 & 31 & 8 & 62 & 1 & 7 \\
\hline 7 & $\begin{array}{l}\text { The services at my bank would help me to give a } \\
\text { good impression towards other people. }\end{array}$ & 0 & 0 & 1 & 7 & 4 & 31 & 8 & 62 & 0 & 0 \\
\hline 8 & I am confident with the security level of my bank. & 0 & 0 & 0 & 0 & 2 & 15 & 9 & 70 & 2 & 15 \\
\hline
\end{tabular}




\section{Conclusion}

The objective of this research is to report on the preliminary findings of the customer relationship management practices among banks from the customers' perspectives. The questionnaires were based on the work of Lu and Shang (2007) with modifications to suit the relevance of this particular study. As far as we are aware there has been no research on this area for the banking sector. Therefore, it is very difficult for us to have a specific and ready-to-use questionnaire to be employed. Thus, we propose a framework which includes five dimensions namely, Customer Acquisition, Customer Response, Customer Knowledge, Customer Information System and Customer Value Evaluation. To enable us to have a reliable and valid instrument, we conduct a pilot test on 13 respondents and our results indicate that our instruments are good to be used with a Cronbach's alpha values ranging from 0.73 to 0.92 . This indicates a good internal consistency of the items in the scale.

The results in this pilot show the respondents either agree or strongly agree on majority of the statements in the dimensions used. This study is significant to banks as they get information on what are items that are important to customers so as to maintain the relationship. From the customers' view, they know that banks are providing excellent services to maintain and strengthen their relationship.

This study is without its limitations. Since this study is a pilot study we hope that we can test on the reliability of the instruments used based on factor analysis.

\section{References}

Almossawi, M. (2001). Bank selection criteria employed by college students in Bahrain: An empirical analysis. International Journal of Bank Marketing, 19 (3): 115-125.

Brown, S. A. (2000). Customer Relationship Management: A Strategic Imperative in the World of E-Business. Canada: John Wiley \& Sons.

Chen, J. S. \& Ching, R. K. H. (2004). An Empirical Study of the Relationship of IT Intensity and Organizational Absorptive Capacity on CRM Performance. Journal of Global Information Management, 12: 1-17.

Dutta, K. \& Dutta, A. (2009). Customer Expectations and Perceptions across the Indian Banking Industry and the Resultant Financial Implications. Journal of Services Research, 9, 31-49.

Gordon, I. (2002). Best practices: Customer relationship management. Ivey Business Journal, November/December, 1-5.

Jham, V. \& Kaleem, M. K. (2008). Customer Satisfaction in the Indian Banking Sector: A Study. IIMB Management Review, 84-93.

Lu, C.S. \& Shang, K.C. (2007). An Evaluation of Customer Relationship Management in Freight Forwarder Services. Proceedings of the $13^{\text {th }}$ Asia Pacific Management Conference, 
Melbourne, Australia. Available at: $h$ ttp://www.proquest.com

Matzler, K., Wurtele, A., \& Renzl, B. (2006). Dimensions of price satisfaction: A study in the retail banking industry. International Journal of Bank Marketing, 24(4), 216-231.

Ndubisi, N. O., Wah, C. K., \& Ndubisi, G. C. (2007), Supplier-customer relationship management and customer loyalty: The banking industry perspective. Journal of Enterprise Information Management, 20 (2), 222-236.

Park, C. H. \& Kim, Y. G. (2003), A Framework of dynamic CRM: Linking Marketing with Information Strategy. Business Process Management Journal, 9, 652-671.

Parvatiyar, A., \& Sheth, J. N. (2001). Customer relationship management: Emerging practice, process and discipline. Journal of Economic and Social Research, 3 (2), 1-34.

Peppers, D. \& Rogers, M. (2004), Managing Customer Relationships: A Strategic Framework. Canada: John Wiley \& Sons.

Rootman, C., Tait, M., \& Bosch, J. (2008). Variables influencing the customer relationship management of banks. Journal of Financial Services Marketing, 13(1), 52-62.

Ryals, L., \& Payne, A. (2001). Customer Relationship Management in Financial Services: Towards Information-Enabled Relationship Marketing. Journal of Strategic Marketing, 9, 3-27.

Sin L.Y.M. Tse A.C.B. \& Yim F.H.K. (2005), CRM Conceptualization and Scale Development, European Journal Market, 39 (11/12), 1264-1290.

Wang, Y., Lo, H. P. Chi, R. \& Yang, Y. (2004). An integrated framework for customer value and customer-relationship-management performance: A customer-based perspectives from China. Managing Service Quality, 14 (2/3), 169-182.

Zineldin, M. (2005). Research and concepts: Quality and customer relationship management (CRM) as competitive strategy in the Swedish banking industry. The TQM Magazine, 17, 329-344. 